\title{
Surfactant treatment for acute respiratory distress syndrome
}

\author{
Jesus López-Herce, Nieves de Lucas, Angel Carrillo, Amaya Bustinza, Ramon Moral
}

\begin{abstract}
Objective-To determine prospectively the efficacy of surfactant in acute respiratory distress syndrome.

Study design-Twenty patients, 1 month to 16 years of age, diagnosed with an acute pulmonary disease with severe hypoxaemia $\left(\mathrm{PaO}_{2} / \mathrm{FiO}_{2}<100\right)(13$ with systemic or pulmonary disease and seven with cardiac disease) were treated with one to six doses of 50-200 $\mathrm{mg} / \mathrm{kg}$ of porcine surfactant administered directly into the trachea. The surfactant was considered to be effective when the $\mathrm{PaO}_{2} / \mathrm{FiO}_{2}$ improved by $>20 \%$.

Results-After initial surfactant administration the $\mathrm{PaO}_{2} / \mathrm{FiO}_{2}$ increased significantly in patients with systemic or pulmonary disease from 68 to 111 , and the oxygenation index (OI) diminished significantly from 36.9 to 27.1 . The $\mathrm{PaO}_{2} / \mathrm{FiO}_{2}$ and $\mathrm{OI}$ did not improve in children with cardiac disease. The improvement of the patients who survived was greater than that of those who died.

Conclusions-Surfactant moderately improves oxygenation in some children with severe acute respiratory distress syndrome secondary to pulmonary or systemic disease.
\end{abstract}

(Arch Dis Child 1999;80:248-252)

Keywords: surfactant; acute respiratory distress syndrome; lung disease

Acute respiratory distress syndrome (ARDS) in children can be secondary to multiple causes acting by different mechanisms, such as: direct endothelial damage, decrease and alteration of surfactant, cellular damage by mediators of inflammation (cytokines, complement, products of coagulation, metabolites of arachidonic acid, proteases, and free radicals), and the activation of platelets and leucocytes. These causes produce an alteration in the alveolar capillary membrane, which results in increased permeability and secondary pulmonary oedema. ${ }^{1}$

Despite the use of new treatments such as controlled pressure ventilation and the inversion of the inspiratory/expiratory ratio, ${ }^{2}$ permissive hypercapnia, ${ }^{3}$ postural changes, ${ }^{4}$ high frequency ventilation, ${ }^{5}$ administration of inhaled nitric oxide, ${ }^{67}$ and extracorporeal membrane oxygenation (ECMO), ${ }^{8}$ the mortality from ARDS is still very high. ${ }^{9} 10$

Several studies have shown, by means of bronchoalveolar lavages, that patients with ARDS show a quantitative and qualitative alteration of surfactant, and this alteration begins in the first phases of the disease. ${ }^{11}{ }^{12}$ The decrease of surfactant in ARDS might be the result of many factors: inactivation of the surfactant by plasma proteins that pass into the alveolus; inhibition or damage to the protein component or phospholipid component of the surfactant by mediators of inflammation, such as lipases, proteases, or oxidants; incorporation of the surfactant into hyaline membranes; alterations of the synthesis, storage, or release of the surfactant as a result of damage to type II pneumocytes; and the loss of the surfactant caused by high volume mechanical ventilation. ${ }^{11}{ }^{12}$ The decrease of
Pediatric Intensive Care Unit, Gregorio Marañon University General Hospital, c/Puentecesures 1.B $1^{\circ}$ B, 28029 Madrid, Spain J López-Herce

$\mathrm{N}$ de Lucas

A Carrillo

A Bustinza

R Moral

Correspondence to:

Dr López-Herce.

email: uciped@ippp.hggm.es

Table 1 Clinical characteristics of the patients with pulmonary or systemic disease

\begin{tabular}{|c|c|c|c|c|c|c|}
\hline Patient & Age & Sex & Diagnosis & $\begin{array}{l}\text { Murray } \\
\text { index }\end{array}$ & $\begin{array}{l}\text { Surfactant } \\
\text { doses }(n)\end{array}$ & Outcome \\
\hline 1 & 1 year & $M$ & $\begin{array}{l}\text { Bronchopneumonia } \\
\text { Tracheo-oesophageal fistula }\end{array}$ & 3 & 2 & Died \\
\hline 2 & 1 month & M & Bronchiolitis & 3 & 4 & Lived \\
\hline 3 & 8 years & $\mathrm{F}$ & $\begin{array}{l}\text { Pneumocystis carinii pneumonia } \\
\text { AIDS }\end{array}$ & 3 & 3 & Died \\
\hline 4 & 16 years & M & $\begin{array}{l}\text { Duchenne muscular dystrophy } \\
\text { Postoperative pneumonia }\end{array}$ & 3 & 3 & Died \\
\hline 5 & 1 year & $\mathrm{F}$ & Meningococcal septicaemia & 3.3 & 4 & Lived \\
\hline 6 & 8 years & $\mathrm{F}$ & $\begin{array}{l}\text { Multiple trauma } \\
\text { Pulmonary contusion }\end{array}$ & 3.6 & 1 & Lived \\
\hline 7 & 10 years & $\mathrm{F}$ & $\begin{array}{l}\text { Crohn's disease } \\
\text { Abdominal surgery } \\
\text { Sepsis }\end{array}$ & 3.7 & 3 & Lived \\
\hline 8 & 4 months & $\mathrm{F}$ & Pseudomona sepsis & 3.3 & 3 & Died \\
\hline 9 & 4 months & M & $\begin{array}{l}\text { P carinii pneumonia } \\
\text { AIDS }\end{array}$ & 3.3 & 2 & Lived \\
\hline 10 & 1 months & M & Bronchiolitis & 3 & 1 & Lived \\
\hline 11 & 6 months & M & $\begin{array}{l}\text { Bronchopulmonary dysplasia } \\
\text { Bronchiolitis }\end{array}$ & 3 & 2 & Lived \\
\hline 12 & 7 years & $\mathrm{F}$ & $\begin{array}{l}\text { Hip surgery } \\
\text { Pneumonia }\end{array}$ & 4 & 1 & Lived \\
\hline 13 & 5 months & $\mathrm{F}$ & $\begin{array}{l}\text { P carinii pneumonia } \\
\text { Neuroblastoma }\end{array}$ & 3.6 & 2 & Lived \\
\hline
\end{tabular}


Table 2 Clinical characteristics of the patients with cardiac disease

\begin{tabular}{lllllll}
\hline Patient & Age & Sex & Diagnosis & $\begin{array}{l}\text { Murray } \\
\text { index }\end{array}$ & $\begin{array}{l}\text { Surfactant } \\
\text { doses }(n)\end{array}$ & Outcome \\
\hline 1 & 1 year & M & Tetralogy of Fallot & 3.6 & 2 & Died \\
2 & 7 months & M & VSD, PHT & 3.3 & 3 & Died \\
3 & 1 year & M & Down's, VSD, PHT & 3 & 2 & Died \\
4 & 4 months & M & Complex cardiopathy & 3 & 2 & Lived \\
5 & 1 year & M & Down's, VSD, PHT & 3 & 2 & Died \\
6 & 11 months & M & Down's, AVSD & 2.6 & 1 & Died \\
7 & 5 months & M & VSD, PHT, bronchiolitis & 2.6 & 1 & Died
\end{tabular}

AVSD, atrioventricular septal defect; PHT, pulmonary hypertension; VSD, ventricular septal defect; Down's, Down's syndrome.

surfactant causes respiratory failure by decreasing compliance and residual pulmonary capacity, the formation of atelectasias, and pulmonary oedema. ${ }^{11} 12$

Multiple studies have shown that the intratracheal administration of surfactant in the newborn with respiratory distress syndrome leads to a great improvement in oxygenation and ventilation, allowing a decrease in respiratory assistance and significantly decreasing mortality. ${ }^{13}$ Despite this, there are few studies that have analysed the efficacy of surfactant in ARDS, either in adults ${ }^{14-17}$ or in newborns and children. ${ }^{18-22}$

\section{Patients and methods}

Between October 1993 and July 1997, surfactant was administered to 20 patients (13 boys and seven girls) aged from 1 month to 16 years, who had been diagnosed with severe ARDS with a Murray index modified for infancy ${ }^{3}$ greater than 2.5 (range, 2.6-4). ARDS was defined as an acute pulmonary disease, non-cardiogenic in origin, with diffuse bilateral infiltrates on the chest $x$ ray, and hypoxaemia with a $\mathrm{PaO}_{2} / \mathrm{FiO}_{2}$ (arterial oxygen tension/ fraction inspired oxygen ratio) lower than $200 \mathrm{~mm} \mathrm{Hg} .{ }^{1}$ We divided the patients in two groups: (1) 13 patients with ARDS secondary

Table 3 Respiratory assistance before the surfactant treatment in patients with pulmonary or systemic disease

\begin{tabular}{llcllll}
\hline Patient & $\begin{array}{l}\text { Peak pressure } \\
(\mathrm{cm} \mathrm{H} \mathrm{O})\end{array}$ & $\begin{array}{l}\mathrm{PEEP} \\
\left(\mathrm{cm} \mathrm{H} \mathrm{H}_{2} \mathrm{O}\right)\end{array}$ & $\begin{array}{l}\text { Frequency } \\
(\mathrm{rpm})\end{array}$ & $\mathrm{I}: \mathrm{E}$ ratio & $\mathrm{FiO}_{2}$ & $\begin{array}{l}\text { Paw } \\
\left(\mathrm{cm} \mathrm{H}_{2} \mathrm{O}\right)\end{array}$ \\
\hline 1 & 52 & 8 & 35 & $1: 1.5$ & 1 & 25 \\
2 & 40 & 7 & 42 & $1: 1$ & 1 & 25 \\
3 & 40 & 7 & 20 & $1: 1$ & 0.75 & 24 \\
4 & 44 & 10 & 20 & $1: 1.5$ & 0.9 & 21 \\
5 & 32 & 8 & 40 & $1: 2$ & 1 & 16 \\
6 & 41 & 14 & 25 & $1: 1$ & 1 & 26 \\
7 & 38 & 10 & 31 & $1: 1$ & 1 & 23 \\
8 & 43 & 12 & 35 & $3: 1$ & 1 & 35 \\
9 & 38 & 4 & 60 & $1: 1.5$ & 1 & 17 \\
10 & 33 & 6 & 60 & $1: 2$ & 1 & 16 \\
11 & 28 & 6 & 40 & $1: 1.5$ & 0.6 & 13 \\
12 & 44 & 16 & 30 & $1 ; 1$ & 1 & 30 \\
12 & 44 & 16 & 30 & $1: 1$ & 1 & 30 \\
13 & 37 & 12 & 27 & $1: 1.5$ & 0.85 & 22 \\
\hline
\end{tabular}

PEEP, positive end expiratory pressure; Paw, mean airway pressure.

Table 4 Respiratory assistance before the surfactant treatment in patients with cardiac disease

\begin{tabular}{lllllll}
\hline Patient & $\begin{array}{l}\text { Peak pressure } \\
\left(\mathrm{cm} \mathrm{H}_{2} \mathrm{O}\right)\end{array}$ & $\begin{array}{l}\mathrm{PEEP} \\
\left(\mathrm{cm} \mathrm{H} \mathrm{H}_{2} \mathrm{O}\right)\end{array}$ & $\begin{array}{l}\text { Frequency } \\
(\text { rpm })\end{array}$ & I:E ratio & $\mathrm{FiO}_{2}$ & $\begin{array}{l}\text { Paw } \\
\left(\mathrm{cm} \mathrm{H}_{2} \mathrm{O}\right)\end{array}$ \\
\hline 1 & 42 & 13 & 32 & $1: 2$ & 1 & 23 \\
2 & 37 & 10 & 26 & $1: 2$ & 1 & 18 \\
3 & 31 & 12 & 35 & $1: 2$ & 1 & 21 \\
4 & 35 & 12 & 30 & $1: 1$ & 0.85 & 21 \\
5 & 31 & 8 & 20 & $1.5: 1$ & 0.6 & 20 \\
6 & 31 & 8 & 35 & $1: 1$ & 0.7 & 18 \\
7 & 40 & 4 & 23 & $1: 1$ & 1 & 18
\end{tabular}

PEEP, positive end expiratory pressure; Paw, mean airway pressure. to pulmonary or systemic disease (table 1 gives their diagnoses and clinical characteristics); and (2) seven patients with hypoxaemic pulmonary pathology in the postoperative period of cardiovascular surgery, in whom the clinical evolution, chest $x$ ray, and echocardiography suggested that the pulmonary alteration could not be attributed to cardiac pathology alone, despite not having monitored the pulmonary capillary pressure. Table 2 gives the diagnoses and clinical characteristics of these patients.

Once informed consent was obtained from the parents of the patients, the surfactant was administered according to a previously established protocol, as compassionate treatment approved by the Institutional Review Board, when faced with the failure of conventional treatment. Our standard treatment for ARDS is controlled pressure ventilation with an $\mathrm{I}: \mathrm{E}$ ratio of $1: 2$ to $3: 1$, positive end expiratory pressure (PEEP) that allows the optimum degree of oxygenation, and an $\mathrm{FiO}_{2}$ necessary to maintain a saturation between $85 \%$ and $90 \%$, with a $\mathrm{PaO}_{2}$ greater than $50-60 \mathrm{~mm} \mathrm{Hg}$, and permissive hypercapnia up to a $\mathrm{PaCO}_{2}$ of $85-90 \mathrm{~mm} \mathrm{Hg}$, maintaining a $\mathrm{pH}$ higher than 7.15-7.20. In patients with pulmonary hypertension in the postoperative period of cardiac surgery, we try to maintain the $\mathrm{pH}$ between 7.45 and 7.50 with hyperventilation and administration of bicarbonate, additional treatment with prostaglandin E1 or prostacyclin, and the administration of inhaled nitric oxide. (We gave inhaled nitric oxide to 15 of our patients, at a concentration of between 3 and $25 \mathrm{ppm}$.) We did not use high frequency ventilation or ECMO, as this is not available in our hospital. Tables 3 and 4 show the ventilation parameters of the patients before the administration of the surfactant.

In 14 of the patients, one to six doses of porcine surfactant (Curosurf) were given at $50 \mathrm{mg} / \mathrm{kg}$ at intervals of between six and 24 hours, with a total of 37 administrations of surfactant. In the remaining six patients, we used surfactant doses of $200 \mathrm{mg} / \mathrm{kg}$, in nine doses. The surfactant was given in two equal aliquots through a tube introduced as distally as possible through the tracheal tube, one towards the right lung and the other towards the left. All patients had continuous electrocardiogram monitoring, as well as central venous pressure (CVP) and intra-arterial blood pressure monitoring. In addition, four patients had pulmonary artery pressure monitoring by means of a catheter passed through the right ventricle during cardiac surgery, and one patient had a Swan-Ganz catheter. A chest $x$ ray and arterial blood gas extraction were performed before the surfactant was administered. Whenever possible, after administration we tried to keep the same parameters on the respirator until new blood gas measurements were carried out. New blood gas controls were performed at 30, 60, 120, 240, and 360 minutes after administering the surfactant. The response was considered to be positive if the $\mathrm{PaO}_{2} / \mathrm{FiO}_{2}$ ratio improved $>20 \%$ in the first four hours after the surfactant was given, without any modification 
Table $5 \mathrm{PaO}_{2} / \mathrm{FiO}_{2}, \mathrm{PaCO}_{2}$, and oxygenation index (OI) before and after the first dose of surfactant treatment in patients with pulmonary or systemic disease

\begin{tabular}{|c|c|c|c|c|c|c|}
\hline \multirow[b]{2}{*}{ Patient } & \multicolumn{2}{|c|}{$\mathrm{PaO}_{2} / \mathrm{FiO}_{2}$} & \multicolumn{2}{|l|}{$O I$} & \multicolumn{2}{|l|}{$\mathrm{PaCO}_{2}$} \\
\hline & Before & After & Before & After & Before & After \\
\hline 1 & 59 & 72 & 43 & 33 & 38 & 38 \\
\hline 2 & 57 & 164 & 43 & 9 & 56 & 35 \\
\hline 3 & 99 & 136 & 24 & 19 & 41 & 25 \\
\hline 4 & 72 & 93 & 29 & 27 & 46 & 43 \\
\hline 5 & 58 & 83 & 27 & 27 & 50 & 66 \\
\hline 6 & 44 & 52 & 60 & 50 & 66 & 65 \\
\hline 7 & 65 & 84 & 48 & 37 & 79 & 100 \\
\hline 8 & 54 & 61 & 65 & 55 & 80 & 83 \\
\hline 9 & 94 & 252 & 18 & 7 & 78 & 65 \\
\hline 10 & 57 & 69 & 25 & 23 & 45 & 25 \\
\hline 11 & 99 & 76 & 13 & 18 & 60 & 59 \\
\hline 12 & 53 & 77 & 56 & 39 & 66 & 65 \\
\hline 13 & 74 & 227 & 29 & 9 & 44 & 33 \\
\hline Mean & 68 & 111.2 & 36.9 & 37.1 & 57.6 & 54 \\
\hline SD & 18 & 64.7 & 16.6 & 15.2 & 15 & 23 \\
\hline
\end{tabular}

$\mathrm{PaCO}_{2}$ measured in $\mathrm{mm} \mathrm{Hg}$.

Increase in $\mathrm{PaO}_{2} / \mathrm{FiO}_{2}, \mathrm{p}<0.01$. Reduction in OI, $\mathrm{p}<0.05$.

of respiratory assistance. We also calculated the oxygenation index (OI; mean pressure in the airway $\times \mathrm{FiO}_{2} \times 100 / \mathrm{PaO}_{2}$ ). When the surfactant improved oxygenation during more than one blood gas control we reduced respiratory assistance (peak of pressure or $\mathrm{FiO}_{2}$, depending of the previous assistance). The administration of a repeated dose depended on the blood gas response to the first dose and the clinical evolution of the patient. Statistical software (BMDP; University of California, Berkeley, California, USA) was used for statistical analysis of the results. Statistical analysis was performed by using analysis of variance, the Student's $t$ test, two tailed Mann-Whitney test, and Wilcoxon test. Values of $p<0.05$ were considered significant.

\section{Results}

In the 13 patients with pulmonary or systemic pathology the mean (SD) $\mathrm{PaO}_{2} / \mathrm{FiO}_{2}$ increased after the first dose of surfactant from 68 (18.4) to $111.2(64.7)(\mathrm{p}<0.01)$ and the mean $(\mathrm{SD})$ OI was reduced from 36.9 (16.6) to 27.1 (15.2). The $\mathrm{PaO}_{2} / \mathrm{FiO}_{2}$ improved $>20 \%$ in 10 patients. There was no significant change in the $\mathrm{PaCO}_{2}$ (table 5). When each of the 33 administrations of surfactant was analysed separately, the mean (SD) $\mathrm{PaO}_{2} / \mathrm{FiO}_{2}$ increased from 73.2 (19.7) to $100.8(49.7)(\mathrm{p}<0.01)$. In 17 of the 33 administrations there was a $>20 \%$ increase in the $\mathrm{PaO}_{2} / \mathrm{FiO}_{2}$. The mean (SD) OI diminished from 34.4 (14) to 28.6 (13.7) ( $\mathrm{p}<0.05)$, and the mean (SD) $\mathrm{PaCO}_{2}$ from 59.9 (16.7) $\mathrm{mm} \mathrm{Hg}$ to 56.8 (23.5; NS).

Table $6 \quad \mathrm{PaO}_{2} / \mathrm{FiO}_{2}, \mathrm{PaCO}_{2}$, and oxygenation index (OI) before and after the first dose of surfactant treatment in patients with cardiac disease

\begin{tabular}{|c|c|c|c|c|c|c|}
\hline \multirow[b]{2}{*}{ Patient } & \multicolumn{2}{|c|}{$\mathrm{PaO}_{2} / \mathrm{FiO}_{2}$} & \multicolumn{2}{|l|}{$O I$} & \multicolumn{2}{|c|}{$\mathrm{PaCO}_{2}$} \\
\hline & Before & After & Before & After & Before & After \\
\hline 1 & 37 & 53 & 61 & 41 & 33 & 42 \\
\hline 2 & 51 & 53 & 35 & 57 & 42 & 42 \\
\hline 3 & 62 & 52 & 30 & 33 & 31 & 33 \\
\hline 4 & 60 & 93 & 29 & 27 & 39 & 46 \\
\hline 5 & 90 & 96 & 22 & 21 & 27 & 31 \\
\hline 6 & 100 & 100 & 18 & 20 & 38 & 33 \\
\hline 7 & 46 & 40 & 30 & 52 & 77 & 75 \\
\hline Mean & 63.7 & 69.5 & 32.1 & 35.8 & 41 & 43.1 \\
\hline SD & 23.1 & 25.5 & 13.9 & 14.6 & 16.6 & 15.1 \\
\hline
\end{tabular}

$\mathrm{PaCO}_{2}$ was measured in $\mathrm{mm} \mathrm{Hg}$.
Table 7 Comparison of the response to surfactant between the patients who died and those who lived

\begin{tabular}{lcl}
\hline & Lived $(n=10)$ & Died $(n=10)$ \\
\hline $\mathrm{PaO}_{2} / \mathrm{FiO}_{2}$ before & $66.7(18.7)$ & $67(22.4)$ \\
$\mathrm{PaO}_{2} / \mathrm{FiO}_{2}$ after & $117.7(70.8)$ & $75.6(30)$ \\
$\mathrm{OI}$ before & $34.8(16)$ & $35.7(15.9)$ \\
OI after & $24.6(14.3)$ & $35.9(14.7)$ \\
\hline
\end{tabular}

Increase of $\mathrm{PaO}_{2} / \mathrm{FiO}_{2}$ and reduction of oxygenation index (OI) in patients who lived, $\mathrm{p}<0.05$.

In the seven patients with cardiac pathology there were no significant changes in $\mathrm{PaO}_{2} / \mathrm{FiO}_{2}$, OI, or $\mathrm{PaCO}_{2}$ after the first dose of surfactant. The $\mathrm{PaO}_{2} / \mathrm{FiO}_{2}$ improved $>20 \%$ in only two patients (table 6). When each of the surfactant administrations was analysed separately, the mean (SD) $\mathrm{PaO}_{2} / \mathrm{FiO}_{2}$ increased from 65.3 (24.7) to 70.6 (22); the $\mathrm{PaO}_{2} / \mathrm{FiO}_{2}$ increased $>20 \%$ in only three of the 13 surfactant administrations. The mean (SD) OI diminished from 36.9 (17.4) to 35 (13.6) and the mean (SD) $\mathrm{PaCO}_{2}$ increased from 34.2 (8.1) to $36.2(9.1 ; \mathrm{NS})$.

The mean (SD) $\mathrm{PaO}_{2} / \mathrm{FiO}_{2}$ increased from 73.4 (20.8) to 115.2 (77.8) after administration of $200 \mathrm{mg} / \mathrm{kg}$ of surfactant, and after 50 $\mathrm{mg} / \mathrm{kg}$ it increased from $70.4(21.6)$ to 86.7 (32.9). The difference between the two doses was not significant. In six of the nine surfactant administrations of $200 \mathrm{mg} / \mathrm{kg}$ there was an increase in the $\mathrm{PaO}_{2} / \mathrm{FiO}_{2}$ of $>20 \%$, whereas this occurred only in 14 of the 37 administrations of $50 \mathrm{mg} / \mathrm{kg}$. There was no correlation between the increase in $\mathrm{PaO}_{2} / \mathrm{FiO}_{2}$ and the patients' ages.

Improvement after the administration of surfactant began between 30 minutes and four hours, with three quarters of the patients showing an improvement in the first hour. The administration of surfactant produced initial hypoxaemia, bradycardia, and hypotension in three patients, in one of them ventilation decreased because of a partial obstruction of the trachea by the surfactant, and in another, a patient with a pneumothorax, an increase of the pneumothorax was found one hour after the administration.

Ten patients died: five as a result of a cardiogenic shock with multiple organ system failure, three because of refractory respiratory failure, one as a result of pulmonary haemorrhage, and one because assistance was withdrawn as a result of the irreversible underlying disease (AIDS). The mortality of cardiac patients with ARDS was greater (six of seven) than that of patients with pulmonary or systemic disease (four of 13). The improvement in the oxygenation of the patients who survived was greater $\left(\mathrm{PaO}_{2} / \mathrm{FiO}_{2}\right.$ increase of 51 points and $\mathrm{OI}$ decrease of 10 points) than that of the patients who died $\left(\mathrm{PaO}_{2} / \mathrm{FiO}_{2}\right.$ increase of 8 and no decrease in OI) (table 7). The differences between the two groups were significant $(\mathrm{p}<0.05)$.

\section{Discussion}

There are only two prospective, comparative studies that analyse the efficacy of surfactant in patients with ARDS, both of which are in adult patients, and one of which suggests that 
surfactant produces an improvement in oxygenation and a decrease in mortality. ${ }^{16}{ }^{17}$ The remaining studies refer to small series of patients. With the exception of the newborn period, there is only one multi-institutional study on children, with 29 patients who were treated with calf surfactant. ${ }^{21}$ The rest of the studies were carried out on small patient populations. ${ }^{18-2022}$

Our objective was to administer surfactant in two different groups of patients, one with ARDS secondary to pulmonary or systemic disease, and other in the postoperative period following cardiovascular surgery .

Our results show that surfactant improved oxygenation in 10 of the 13 children with severe ARDS secondary to pulmonary or systemic disease, which was refractory to conventional ventilation. However, in most of our patients the improvement in oxygenation was moderate and the effect on prognosis was probably minimal in all but four of these children.

In cardiac patients, the surfactant did not produce significant changes in oxygenation. The $\mathrm{PaO}_{2} / \mathrm{FiO}_{2}$ increased significantly from 60 to 93 in one patient only (table 6). Although it has been shown that extracorporeal circulation alters pulmonary surfactant, and that this might contribute to altered respiratory function in the postoperative period of cardiac surgery, ${ }^{23}$ a recent study showed that the lecithin to sphingomyelin ratios and surfactant protein A concentrations were reduced in tracheal secretions of children with bacterial pneumonia, viral pneumonia, and ARDS, but not in children on cardiopulmonary bypass. ${ }^{24}$ Our results suggest that in these patients surfactant might have a lower efficacy because pulmonary hypertension and pulmonary oedema secondary to cardiac failure might be more important factors in the development of pulmonary damage. Unfortunately, although four of the patients in the postoperative course of cardiac surgery had a catheter in the pulmonary artery, none of them had a Swan-Ganz catheter, and thus we do not know the pulmonary capillary pressure, which is why some of the children in the postoperative course of cardiac surgery might have presented with a mixed ARDS disease with acute cardiac pulmonary oedema. Two studies in which surfactant was administered to adults subjected to extracorporeal surgery, who did not present with ARDS, produced discordant results. ${ }^{25} 26$ We have not found any studies on the use of surfactant in children with ARDS secondary to extracorporeal cardiac surgery.

In our patients, we did not find any other previous clinical or respiratory parameter that could predict the response to treatment with surfactant. Experimental studies have found that the response to surfactant depends on the type of pulmonary injury, the degree of alteration, and the presence of surfactant inhibitory serum proteins in the alveoli. ${ }^{27}$ Other factors that may play a part in the response to treatment are: (1) the time of administration (the sooner it is administered the greater the effects), ${ }^{27}$ (2) the type of surfactant (natural surfactants are more effective than synthetic ones), ${ }^{28}$ (3) the form of administration (direct tracheal administration is more effective than an aerosol), ${ }^{27}$ (4) the volume of liquid administered, ${ }^{14}{ }^{29}$ and the dose of surfactant and the number of administrations. ${ }^{14}{ }^{27}$ In our study, the patients who received a dose of $200 \mathrm{mg} / \mathrm{kg}$ of surfactant had a better response, although this was not significant, perhaps because of the small number of patients treated with this dose. The surfactant was always administered quite late when there was severe hypoxaemia and the patients did not respond to conventional treatment. We have no way of knowing whether earlier administration of the surfactant would have given better results. In any case, surfactant would not be expected to be as effective in ARDS in children and adults as it is in newborns, because the surfactant deficit is only one of the factors that lead to the pulmonary alteration in these patients. ${ }^{30}$

We used the rapid instillation technique as the surfactant delivery method. Several experimental studies have shown that direct instillation through the tracheal tube or through a bronchoscopy is more effective than aerosolised surfactant or the five minute infusion technique..$^{27} 3031$ However, in some patients rapid instillation produces significant decreases in oxygen saturation, heart rate, and blood pressure, as occurred in three of our patients, probably secondary to the transitory disconnection of the respirator. ${ }^{16}{ }^{30}$ These effects can be avoided if the surfactant is given through a tracheal tube without interrupting the mechanical ventilation. Another factor that might limit the use of surfactant is its high cost, especially in older children and adolescents. ${ }^{32}$

Our patients had a high mortality rate despite treatment with surfactant. This might be because of the selection of patients with ARDS who did not respond to conventional treatment, and the inclusion of patients with ARDS in the postoperative course of cardiac surgery in whom pulmonary hypertension and cardiogenic shock were also found. The mortality of patients with ARDS secondary to pulmonary or systemic disease was four of 13, and the mortality of cardiac patients was six of seven. According to our results, the positive response to surfactant could be a prognostic factor in children with ARDS.

We conclude that the administration of intratracheal surfactant moderately improves oxygenation in some children with secondary pulmonary pathology or systemic disease. However, our study does not show whether surfactant changes the prognosis of children with ARDS. Further studies are necessary to determine the time of administration, the dose, the interval, and the specific indications of surfactant in the different pathologies that cause ARDS in childhood.

The authors thank the paediatric intensive care unit nursing staff for their cooperation and assistance.

1 Bernard GR, Artigas A, Brigham KL, et al. Report of the American-European consensus conference on ARDS: definitions, mechanisms, relevant outcomes and clinical trial coordination. Intensive Care Med 1994;20:225-32. 
2 Morris AH, Wallace CJ, Menlove RL, et al. Randomized clinical trial of pressure-controlled inverse ratio ventilation and extracorporeal $\mathrm{CO}_{2}$ removal for adult respiratory 295-305.

3 Hicling KG, Walsh J, Henderson S, Jackson R. Low mortality rate in adult respiratory distress syndrome using low-volume, pressure-limited ventilation with permissive hypercapnia: a prospective study. Crit Care Med 1994;22: 1568-78

4 Murdoch IA, Storman MO. Improved arterial oxygenation in children with the adult respiratory distress syndrome: the prone position. Acta Paediatr 1994;83:1043-6.

5 Arnold JH, Hanson JH, Toro-Figuero LO, Gutierrez J, Berens RJ, Anglin DL. Prospective, randomized comparison of high-frequency oscillatory ventilation and conventional mechanical ventilation in pediatric respiratory failure. Crit Care Med 1994;22:1530-9.

6 Rosaint R, Falke KJ, López F, Slama K, Pison U, Zapol WM. Inhaled nitric oxide for the adult respiratory distress WM. Inhaled nitric oxide for the adult respir
syndrome. N Engl f Med 1993;328:399-405.

7 López-Herce J, Cueto E, Carrillo A, Vázquez P, Bustinza A, Moral R. Respuesta aguda a la administración de óxido nítrico en niños. An Esp Pediatr 1997;46:581-586.

8 Moler FW, Custer JR, Barlett RH, et al. Extracorporeal life support for severe pediatric respiratory failure; an update experience 1991-1993. F Pediatr 1994;124;875-80.

9 DeBruin W, Notterman DA, Magid M, Godwin T, Johnston $\mathrm{S}$. Acute hypoxemic respiratory failure in infants and children: clinical and pathologic characteristics. Crit Care Med 1992;20:1223-34.

10 Davis SL, Furman DP, Costarino AT. Adult respiratory distress syndrome in children: associated disease, clinical course, and predictors of death. F Pediatr 1993;123.35-45.

11 Lewis JF, Jobe AH. Surfactant and the adult respiratory distress syndrome. Am Rev Respir Dis 1993;147:218-33.

12 Gregory TJ, Longmore WJ, Moxley MA, et al. Surfactant chemical composition and biophysical activity in acute respiratory distress syndrome. F Clin Invest 1991;88:197681 .

13 Collaborative European Multicenter Study Group. Surfactant replacement therapy for severe neonatal respiratory distress syndrome: an internation trial. Pediatrics 1988;82:683-91.

14 Gommers D, Lachmann B. Surfactant therapy in the adult patient. Curr Opin Crit Care 1995;1:57-61.

15 Haslam PL, Hughes DA, MacNaughton PD, Baker CS, Evans TW. Surfactant replacement therapy in late-stage adult respiratory distress syndrome. Lancet 1994;343. 1009-11.

16 Anzueto A, Baughman RP, Guntupalli KK, et al. Aerosolized surfactant in adults with sepsis-induced acute respiratory distress syndrome. Exosurf Acute Respiratory Distress Syndrome Sepsis Study Group. $N$ Engl $\mathcal{F}$ Med 1996;334:1417-21
17 Gregory TJ, Gadek JE, Weiland JE, et al. Survanta supplementation in patients with acute respiratory distress syndrome (ARDS) [abstract]. Am 7 Respir Crit Care Med

18 Lachmann B. The role of pulmonary surfactant in the pathogenesis and therapy of ARDS. In: Vincent JL, ed. Update in intensive care and emergency medicine. Berlin: Springer-Verlag, 1987:123-34

19 Marraro G, Casiraghi G, collaborative study group on surfactant replacement in infants. Porcine natural surfactant in infants with adult respiratory distress syndrome (ARDS). Pediatr Res 1995;37:287.

20 Aldamiz-Echevarría L, Rodriguez J, Arana J, Emparanza JI, Izquierdo MA, Landa J. Presentación de un lactante afecto de distrés respiratorio tipo adulto y tratado con surfactante pulmonar. An Esp Pediatr 1994;40:311-12.

21 Wilson DF, Jiao JH, Bauman LA, et al. Calf's lung surfactant extract in acute hypoxemic respiratory failure in children. Crit Care Med 1996;24:1316-22.

22 Moreno M, López-Herce J, Merello C, Alcaraz A, Carrillo A. Exogenous surfactant therapy for acute respiratory disA. Exogenous surfactant therapy for acute resp
tress in infancy. Intensive Care Med 1996;22:87.

23 McGowan FX, Ikegami M, Del Nido PJ, et al. Cardiopulmonary bypass significantly reduces surfactant activity in children. F Thorac Cardiovasc Surg 1993;106:968-77.

24 LeVine AM, Lotze A, Stanley S. Surfactant content in children with inflammatory lung disease. Crit Care Med 1996; 24:1062-7.

25 Do Campo JL, Bertarnou EG, De Lorenzi A, Hager AA. Nebulised exogenous natural surfactant after cardiac surgery. Lancet 1994;343:482.

26 Macnaughton PD, Evans TW. The effect of exogenous surfactant therapy on lung function following cardiopulmonary bypass. Chest 1994;105:421-5.

27 Lewis JF, Veldhuizen RAW. Factors influencing efficacy of exogenous surfactant in acute lung injury. Biol Neonate 1995;67(suppl 1):48-60.

28 Cummings JJ, Holm BA, Hudak ML, Hudak BB, Ferguson WH, Egan EA. A controlled clinical comparison of four different surfactant preparations in surfactant-deficient preterm lambs. Am Rev Respir Dis 1992;145:999-1004.

29 Van der Bleek J, Plötz FB, van Overbeek M, et al. Distribution of exogenous surfactant in rabbits with severe respiratory failure: the effect of volume. Pediatr Res 1993;34: 154-8.

30 Evans DA, Wilmott RW, Whitsett JA. Surfactant replacement therapy for adult respiratory distress syndrome in children. Pediatr Pulmonol 1996;21.328-36.

31 Segerer H, Scheid A, Wagner M, Obladen M. Tracheal surfactant infusion during 5 minutes is less effective than bolus instillation in rabbits [abstract]. Pediatr Res 1994;36: $37 \mathrm{~A}$

32 Gregory GA, Phibbs RH. Surfactant replacement for respiratory failure: lessons from the neonate. Anesth Analg 1993;76:465-6. 